DOI: https://doi.org/10.32689/2523-4536/59-4

УДК 33:331.1

Дмитренко Г. А.

доктор економічних наук, професор,

завідувач кафедри управління персоналом та економіки праці, ПрАТ «ВН3 «Міжрегіональна Академія управління персоналом»

ORCID: https:/orcid.org/0000-0002-8211-5690

Головач Н. В.

кандидат педагогічних наук, доцент кафедри управління персоналом та економіки праці, ПрАТ «ВНЗ «Міжрегіональна Академія управління персоналом» ORCID: https:/orcid.org/0000-0002-6215-6575

Dmytrenko Hennadiiy

Doctor of Economic Sciences, Professor, Head at the Department of Personnel Management and Labor Economics, Private Joint-Stock Company «Higher education institution «Interregional Academy of Personnel Management»

Holovach Nataliia

Candidate of Pedagogical Sciences, Senior Lecturer at the Department of Personnel Management and Labor Economics, Private Joint-Stock Company «Higher education institution «Interregional Academy of Personnel Management»

\title{
МОЖЛИВОСТІ ПІДВИЩЕННЯ КОНКУРЕНТОСПРОМОЖНОСТІ ВІТЧИЗНЯНОЇ ЕКОНОМІКИ $З$ ОПОРОЮ НА ЛЮДСЬКІ РЕСУРСИ
}

\author{
POSSIBILITIES OF INCREASING THE COMPETITIVENESS \\ OF THE DOMESTIC ECONOMY BASED ON HUMAN RESOURCES
}

Розкривається сутність економіки з позииій первинності людської діяльності і професійно-особистісних якостей тих, хто в тому числі керує економікою, тобто управлінської еліти. Акцентовано увагу на людиноцентричній сутності економіки. Пояснення людиноцентричної сутності економічного розвитку детально розкривається з ознайомлення з поняттям «економіка» з різних джерел. Підкреслено призначення економіки - впливати на підвишення якості життя населення країни. Сутність поняття людиночентричностіне проглядається ні з боку задоволення людських потреб, для чого, власне, $i$ функціонує економіка, ні з боку людської діяльності. Наголошується на тому, шо людська діяльність забезпечує функціонування економіки з використанням природних ресурсів і різних засобів технічного характеру, які сама ж людина і створила. Наведено багато суджень відомих вчених Заходу, які зрозуміли глибинні основи економіки, шо пов'язані з людською діяльністю. Наведено різні визначення поняття «економіка» з метою зрозуміння ї̈ «людської» сутності, шоб шукати шляхи ї̈ розвитку у правильному напрямі. Представлені певні приклади, які обгрунтовують первинність людського фактору в розвитку економіки. Первинність людської діяльності розглянуто і в інших економічних прочесах, зокрема економічних кризах міжнародного масштабу. Наведені приклади розвитку економіки зарубіжних країн щзодо формування ефрективних економік, пов'язаних з якістю життя громадян різних країн. Розкрито ігнорування значущості ролі людських ресурсів в вітчизняних економічних процесах. Розкрито ментальну схильність правлячих еліт на східнослов'янських землях, з давніх часів до сьогодення, щчо доводить нехтування людської прачі. Рекомендовано змінити иңю національну ментальну рису: владі потрібно організувати суспільство навколо близьких їм людиночентричних кінцевих результатів діяльності державних структур з потужною мотивачією їх одержання на основі зворотного зв 'язку. Розглянуто людиночентричний шлях розвитку економіки держави-міста Сінгапур, який проклав прем'єр-міністр Лі Куан Ю. Наведений приклад розвитку економіки Японії, щзо пояснюється умінням використовувати людський потенціал країни в інтересах суспільства $i$ самих носїв изього потенціалу.

Ключові слова: людиноцентризм, сутність економіки, первинність людських потреб $i$ діяльності, людські якості, якість управлінської еліти, професіоналізм, конкурентоспроможність економіки та ін.

The essence of the economy is revealed from the standpoint of the primacy of human activity and professional and personal qualities of those who, among other things, manage the economy, ie the management elite. Emphasis is placed on the human-centered essence of the economy. The explanation of the human-centered essence of economic development is revealed in detail from the acquaintance with the concept of "economy" from various 
sources. The purpose of the economy is to influence the improvement of the quality of life of the country's population. The essence of the concept of human-centered is not seen either in terms of meeting human needs, for which, in fact, the economy operates, or in terms of human activity. It is emphasized that human activity ensures the functioning of the economy with the use of natural resources and various technical means, which man himself has created. There are many judgments of well-known Western scientists who have understood the deep foundations of economics related to human activity. Various definitions of the concept of "economy" are given in order to understand its "human" essence, to look for ways to develop it in the right direction. There are some examples that justify the primacy of the human factor in economic development. The primacy of human activity is considered in other economic processes, including economic crises of international scale. Examples of foreign economic development in relation to the formation of efficient economies related to the quality of life of citizens of different countries are given. Ignoring the significant role of human resources in domestic economic processes is revealed. The mental tendency of the ruling elites in the East Slavic lands, from ancient times to the present, is revealed, which proves the neglect of human labor. It is recommended to change this national mental trait: the authorities need to organize the society around the human-centered end results of the activities of state structures with a strong motivation to receive them on the basis of feedback. The man-centered path of economic development of the city-state of Singapore, laid by Prime Minister Lee Kuan Yew. The example of Japan's economic development is explained by the ability to use the country's human potential in the interests of society and the bearers of this potential.

Keywords: anthropocentrism, the essence of the economy, the primacy of human needs and activities, human qualities, the quality of the management elite, professionalism, the competitiveness of the economy, etc.

Актуальність теми. Первинність людської діяльності в економічних процесах вже не потребує доказів. Водночас нерозкритим залишається питання людиноцентричного аспекту сучасної економіки, яка базується на широкому використанні досягнень науково-технічного прогресу. Для цього треба звернути особливу увагу на дві обставини. Перша 3 них - це первинність людини і людської діяльності абсолютно у всіх науковотехнічних і соціально-економічних процесах. Друга - особливості розвитку сучасної Західної демократії, що все більше потерпає від масового розповсюдження егоцентризму в суспільствах і ослаблення контактів між владою і громадянами (народом). Якщо враховувати ці дві обставини, то надвелике значення має роль людського фактору (з історично обумовленими ментальними рисами) у підвищенні рівня конкурентоспроможності вітчизняної економіки.

Аналіз попередніх досліджень. Проблема первинності людської діяльності в економічних процесах так чи інакше почала розглядатися ще класиками політекономії А. Сміто і Д. Рікардо через працю людей. 3 часом це затверджували в своїх наукових працях відомі вчені і практики з економіки та управління: Аджемоглу Д., Робінсон Дж., Друкер П., Макконел К.Р., Брю С.Л., Флін Ш.М., Тейлор Ф.У., Форд Г., Фрідман Дж. Достатньо чітко дана позиція відображена в діях видатного стратега сучасності Лі Куан Ю [7]; відомого за кордоном українського вченого (члена Римського клубу) Богдана Гаврилишина; в працях окремих відомих вітчизняних вчених Головатого М.Ф., Дмитренка Г.А., Солодкова В. [2], а також Щокіна Г.В. [14], якому належить видатний висновок стосовно того, що у XXI сторіччі соціально-економічний розвиток країн буде залежати не від природних чи матеріальних і навіть фінансових ресурсів, а тільки від людських ресурсів. На жаль, у вітчизняній практиці управління економікою рішення цієї проблеми не одержало потрібної уваги для реального втілення за принципом: які люди, так вони і будуть діяти.

Мета статті - розкрити можливості підвищення конкурентоспроможності вітчизняної економіки з опорою на людські ресурси країни, спираючись на дослідження вітчизняних вчених та видатних закордонних управлінців і економістів.

Виклад основного матеріалу. Взагалі процес пояснення людиноцентричної сутності економічного розвитку доцільно розпочати 3 ознайомлення 3 поняттям «економіка» 3 різних джерел, у тому числі відомих і не зовсім відомих широкому колу економістів. В багатьох вітчизняних наукових виданнях «економіка» розглядається як функціонування взаємопов'язаних чотирьох фаз: виробництва, обміну, розподілу і споживання. 3 усіх вищенаведених визначень поняття «економіка» побачити іiї людиноцентричну сутність неможливо. Ця сутність не проглядається ні 3 боку задоволення людських потреб, для чого, власне, і функціонує економіка, ні з боку людської діяльності. В той же час саме ця діяльність взагалі забезпечує функціонування економіки, але вже з використанням природних ресурсів і різних засобів технічного характеру, які сама ж людина і створила.

В цьому сенсі сучасна економічна наука більш глибоко трактує сутність економіки, маючи на увазі обмеженість природних ресурсів та кінцеву ціль функціонування економіки, пов'язану 3 людиною. Наприклад, відомі вчені США такі як С. Фішер, Р. Дорнбуш, Р. Шмалензі визначили, що взагалі економіка відповідає на такі питання: «Яким чином суспільство 3 обмеженими та 
дефіцитними ресурсами вирішує що, як і для кого виробляти товари та послуги» $[12$, с. 1]. В цьому визначенні вже проглядаються паростки людиноцентричної сутності економіки, в тому числі в контексті кінцевої цілі функціонування економіки.

В наступному визначенні сутності економіки вже іншими американськими вченимиекономістами К.Р. Макконнеллом і С.Л. Брю абсолютно чітко вказується на первинність людської діяльності: «Економікс (теорія уnравління) - ие дослідження поведінки людей в проиесі виробництва, розподілу і спожсивання матеріальних благ та послуг в умовах обмежених ресурсів» [12, с. 3].

Можна навести ще багато суджень відомих вчених Заходу, які зрозуміли глибинні основи економіки, що пов'язані з людською діяльністю. Нагадаємо вислів класика сучасного менеджменту та Пітера Друкера про те, що економічні результати не $\epsilon$ продуктом дії якихось економічних сил, а вони досягається людиною [6]. Такої ж думки додержуються великі практики зі США, всесвітньо відомі Фредерік Тейлор, Генрі Форд та ін., результати діяльності яких мали надзвичайний вплив на розвиток світової економіки [11].

Звернули увагу на людиноцентричну сутність економіки вже і деякі вітчизняні вчені, які навіть надали своє визначення: «Економіка - ие сукупність різних взаємодіючих організачій (інститутів), діяльність яких обумовлюється поведінкою людей з метою визначення суспільних благ та забезпечення ï виготовлення, розподілу $i$ споживання в умовах обмежених дефіичтних ресурсів» [5, c. 12].

Взагалі-то може бути велика кількість різних визначень поняття «економіка», але головне - ие зрозуміти ї̈ «людську» сутність, щчоб шукати шляхи ї̈ розвитку у правильному напрямі.

Допомогти процесу усвідомлення первинності людського фактору в розвитку економіки може наведення певних прикладів.

Розглянемо спочатку простий побутовий приклад. Якщо людина почне озиратися навколо себе, то вона побачить багато різних предметів та явищ, що оточують іiі у квартирі, на вулиці, на природі, чи в інших місцях. Але всю цю множину можна поділити всього лише на дві групи: результати діяльності людини та природні явища (як результати «діяльності» природи). Інша справа, що в своїй діяльності з одержання цих результатів, людина використовує різні технічні засоби i технології (що є результатом також діяльності людей) чи природні ресурси. Останні не вва- жаються ресурсом, якщо не можуть бути використані для задоволення суспільних потреб.

Тобто, з цього прикладу можна побачити, яку роль грає людська діяльність щодо виготовлення одягу, меблів, автомобілів, будинків, мобільних телефонів, телевізорів, винаходу Інтернету та ін. I навіть, якщо якийсь продукт виготовляється виключно роботами в автоматизованому режимі, то самі ці роботи і програми, за якими вони працюють, також $\epsilon$ результатом людської діяльності, але вже більш інтелектуальної.

Але як побачити первинність цієї діяльності в інших економічних процесах, зокрема економічних кризах міжнародного масштабу? В цьому сенсі слід звернутися до компетентності видатного стратега сучасності, автора соціально-економічного дива в державі Сінгапур, яка мала тільки один ресурс - людський (та ще у вигляді різномовного та і багатоетнічного населення). Мова йде про Лі Куан Ю. та його визначення сутності економічної кризи 2008 року: «Як тільки голова федерального резерву США вирішив, щзо немає потреби регулювати деривативи та ијіні папери $i$ контролювати їx, гніт вибухового пристрою був підпалений. Коли приймається рішення змішати хороші та сумнівні цінні nапери в одну купу i пустити їх на власний страх і ризик по всій Європі та інших частинах світу, започатковується щось на кшталт фінансової піраміди, яка рано чи пізно розвалиться... Людина, зайнята у сфері фінансів, має на меті домагатися найбільшої вигоди особисто для себе, тому просто засуджувати банкірів і тих, хто отримує прибуток, немає сенсу. Ви дозволили існувати таким правилам, тому вони працюють в рамках циих правил...» [7, с. 127].

Отже, конкретні некомпетентні люди прийняли конкретне рішення, а інші люди використали його в своїх інтересах в рамках дозволеного. Це призвело до несподіваних наслідків щодо зниження ефективності економік різних держав, що відобразилось негативним чином на якості життя їх населення.

Практично за таким же сценарієм, але вже на певному аморальному фоні, розпочалася економічна криза в Україні (яка затягнулася майже на 30 років до сьогодення). Певні некомпетентні люди - представники політичної еліти ще в радянські часи - ненавмисно (а може навпаки) забули дописати в законі «Про кооперацію» 1989 р. одне важливе положення. Зокрема, що дія цього закону розповсюджується тільки на формування та діяльність кооперативів виробничого і науково-прикладного характеру. 
Дійсно, пусті прилавки магазинів у 80-Х роках ХХ ст. підтвердили факт неконкурентоспроможності планової економіки. Щоб якось змінити ситуацію на краще, зробили спробу розвивати кооперативний рух, щоб наповнити прилавки принаймні найнеобхіднішими товарами. Але не вдалося. Більш того, «гніт вибухового пристрою» після прийняття цього закону «був підпалений» дуже специфічним чином. 3 одного боку, дозвіл діяти одержали кооперативи всіх видів. 3 іншого боку, банки надавали короткострокові кредити під надвисокі проценти. В той же час для розвитку кооперативів виробничого профілю потрібні були кредити не менш ніж на два-три і більше років. Таким чином, був даний старт потужної активізації кооперативів спекулятивного профілю. Тобто брати та швидко віддавати кредити могли тільки ті, хто купляв та перепродавав за завищеними цінами товари, які вже були вироблені. Справа доходила навіть до того, що вироблена продукція, яка де-юри знаходилась на складах виробника, декілька разів перепродавалася різними кооперативами, допоки доходила до споживача за надвисокими цінами. В умовах товарного дефіциту за рахунок пересічних громадян здійснювалося збагачення окремих людей, які мали корумповані зв'язки 3 владою, без будь-якого руху в напрямі розвитку економіки, побудови нових підприємств та ін. Цей процес затягнувся на три десятки років та бувзбагаченийрізнимикорупційнимисхемами. Цю ситуацію досить влучно характеризує вислів Генрі Форда - самого чесного міліонера, який сприяв виходу Америки з Великої депресії і становленню капіталізму 3 «людським обличчям»: «Спекуляція готовими товарами - це не бізнес, а більш-менш пристойний різновид крадіжки» [5, с. 11$]$.

Отже, одні люди приймають закони, інші люди надають кредити (банкіри), треті збагачуються за рахунок більшості громадян, що суттєво знижує потенціал економіки в напрямі виконання нею свого призначення впливати на підвищення якості життя населення країни.

Наведемо ще один потужний приклад первинності людської діяльності у формуванні ефективних економік, пов'язаний 3 якістю життя громадян різних країн, який наводять два відомі професори зі США Дарон Аджемоглу і Джеймс Робінсон у своєму науковому бестселері «Чому нації занепадають» [1]. Свої дослідження вони розпочали 3 порівняння життя людей у двох частинах одного і того ж міста Ногалес, яке розділене навпіл парканом. Одна частина відноситься до США, що у штаті Аризона, друга - до Мексики, у штаті Сонора. Вчені прийшли висновку, що життя людей по різні боки паркану дуже відрізняється, починаючи 3 середньорічного доходу на одне господарство. В частині, що належить США, він складає 30 тис. доларів, в іншій частині - близько 10 тис. доларів. Крім того, жителі першої частини «мають доступ до економічних інститутів в США, що дає їм змогу вільно обирати професію, здобувати освіту, набувати професійних навичок, ... а також до політичних інститутів, що дає їм змогу брати участь у демократичному процесі, обирати своїх представників і змінювати їx у разі невідповідної поведінки. Внаслідок цього, політики надають основні послуги (від охорони громадського здоров'я до доріг і охорони правопорядку), яких потребує населення» [1, с. 13].

Досліджуючи ще країни Південної та Північної Кореї, а також багато інших держав на всіх континентах світу, професори Гарвардського університету i Університету Чикаго дійшли фундаментального висновку.

Мова йде про те, що економічний успіх краӥн не залежить від клімату, географічного положення, культури, мови. Цей успіх залежить від діяльності людей в економічних $i$ політичних інститутах, які можуть бути інклюзивні - прогресивні та екстрактивні, тобто регресивні. У першому випадку Уряд підзвітний громадянам $i$ реагуе на їх потреби, а абсолютна більшість населення може користуватися економічними можливостями» [1, с. 9]. Нагадаємо що під «інститутом» розуміється сукупність взаємодіючих організацій, об'єднаних загальною місією.

Д. Аджемоглу та Дж. Робінсон переконані, що «Економічно нації занепадають через екстрактивні інститути. Ці інститути утримують бідні країни в бідності й не дають їм стати на шлях економічного розвитку... У всіх випадках основою інститутів є еліта, що підлаштовує економічні інститути для свого збагачення, своєї влади за рахунок величезної більшості членів суспільства» [1, с. 346-347].

При цьому характерні інші висновки професорів зі США стосовно іноземної допомоги у взаємозв' язку з економічними і політичними інститутами. Вони стверджують: "Оскільки корені бідності - в інститутах, іноземна допомога при системі наявних екстрактивних інститутів у начіях-реципієнтах нічого не зробить для досягнення стійкого розвитку» [1, с. 395]. Дійсно, ця допомога використовуються виключно для утримування статус-кво та зовсім не вкладається в розвиток інклюзивних інститутів. Що стосується 
взаємовідносин економічних і політичних інститутів, то за визначенням професорів зі США економічні інститути грають головну роль в розвитку економіки, але діють вони під впливом політичних сил. Отже, автори наукового бестселера «Чому нації занепадають» грунтовно підтверджують, що нам в Україні немає кого звинувачувати, коли майже за 30 років ми самі не можемо сформувати прогресивну еліту, яка, в свою чергу, забезпечила б прогресивне функціонування політичного $і$ економічного інститутів.

Наведемо деякі приклади ігнорування i опори на людські ресурси в економічних процесах. Мова йде про ментальну схильність правлячих еліт на східнослов'янських землях, 3 давніх часів до сьогодення, нехтувати людьми праці. I це продовжується в той час, коли на Заході відбувається процес цивілізаційного формування культури поваги до прав людини і становлення загальнолюдської моралі в суспільстві. Вперте небажання правлячих структур бачити в людях праці таких, що є особистостями і головною продуктивною силою суспільства, проявлялася в різних аспектах, хоча за радянські часи, декларативним чином, намагались щось зробити для зміни ситуації. Але й досі головним $є$ фактор низької винагороди за результати якісної праці. Прояви цього фактору спостерігаються ще з історичних часів. В Україні ця традиція 3 ментальними коріннями не зникла до сьогодення саме тому, що наскрізним чином повністю охопила найкорумпованішу в Європі систему державного управління. В ній працюють люди зі своїми спотвореними цінностями, потребами, здібностями, національними і людськими якостями та ін.

Щоб змінити цю національну ментальну рису, владі потрібно організувати суспільство навколо близьких їм людиноцентричних кінцевих результатів діяльності державних структур з потужною мотиваиією їх одержання на основі зворотного зв'язку [5; 12].

Але оскільки цей управлінський аспект не $\epsilon$ предметом даного дослідження, додамо лише одне: в Україні зробити це дуже важко, бо, на думку дійсного патріоту, не байдужого до ii долі, великого українця за кордоном, члена Римського клубу Богдана Гаврилишина, «при владі немає порядних, патріотичних, компетентних людей» [12]. Як бачимо, дійсно - ні клімат, ні географічне положення, ні природні чи матеріальні і навіть фінансові ресурси не мають такого суттєвого впливу на розвиток країн і їх економіки як рівень людського потенціалу. А тому, з якими здібностями, якостями і цінностями будуть при владі люди, такими будуть і рішення стосовно розвитку країни.

Для підтвердження і посилення цієї тези, наведемо два коротких приклади із далекого та близького історичного минулого розвитку інших держав. Один 3 них стосується повного занепаду країни завдяки відсутності у людей при владі здібностей до управління. Другий - навпаки присвячено потужному підйому країни з глибинного занепаду до стану розквіту завдяки людській діяльності здатних до управління людей. В першому випадку мова йде про Францію XIV століття, а в другому - про Сінгапур у період $360-\mathrm{x}$ років ХХ століття до сьогодення.

Щодо Франції приклад наведено всесвітньо відомим істориком, мислителем, письменником М. Дрюоном у книзі: «Коли король губить Францію» [13]. Зокрема, він пише: «На початку XIV століття Франиія була найбільи могутньою, найбільш густонаселеною, найбільш багатою країною в усьому християнському світі... Як же могло так статися, щзо 40 років потому ия сама Франиія... розбилася на ворогуючі між собою партії; щзо ї̈ народ потерпав під непосильним тягарем податків; шо провіниії відпадали одна за одною; щцо над владою відкрито сміялися; гроші знецінювалися; чесна комериія була паралізована і всюди панувала бідність; ніхто не знав, щзо принесе йому завтрашній день».

Протилежну ситуацію можна розглянути на прикладі держави-міста Сінгапур і його першого прем’єр-міністра Лі Куан Ю. Останній прийшов до влади, коли прибуток на душу населення становив близько 400 доларів на рік, а сьогодні він перевищує 50 тисяч [7, с. 6].

Зі своєю здатністю бачити сутність речей завдяки аналітичним здібностям і стратегічному мисленню, він визначив вектори розвитку держави. По-перше, це опора на людські ресурси (а саме інтелект, організованість та винахідливість), що повинні замінити природні ресурси, яких в країні практично не було. По-друге, це наведення порядку всередині країни. «Спочатку треба навести лад у власній країні, потім докласти зусиль, щоб подолати ворожість своїх сусідів та етнічні розходження всередині, досягаючи хороших результатів у своєму розвитку» $[7$, с. 5$]$.

Характерною особливістю підйому країни стало виокремлення Лі Куан Ю людського фактору як ключового в розвитку економіки і взагалі суспільства, в якому люди отримують винагороду відповідно до своїх здібностей і внеску в життя суспільства... прогрес суспільства можливий лише за умови заохо- 
чення людей до того, щоб вони максимально служили своїми силами та талантами на благо суспільства [7, с. 169].

При цьому, Лі Куан Ю, маючи великий особистий практичний досвід побудови відповідної держави, стверджував, що «цілкком можливо створити суспільство, в якому кожен отримує неоднакову винагороду за свої зусилля, а однакові можливості, а рівень винагороди визначається не обсягом приватної власності, а залежно від внеску тієї чи іншої особи в життя суспільства, в якому ця особа живе. Інакше кажучи, суспільство (влада в першу чергу) має зробити так, щоб люди вважали корисним і вигідним для себе працювати на його благо. Саме в цьому полягає шлях до прогресу» [7, с. 169].

Апріорі це можливо зробити в кожній організації, якщо цілі і кінцеві результати їх функціонування будуть суспільно корисними і наочними, а кожен працівник має «сродню» працю (за Г. Сковородою) й гідну винагороду за іiі результати як частку суспільно-корисних. Тоді цілі організації стають особистими цілями кожного працюючого. Але це залежить від якості державного управління i, більш конкретно, від якості управлінської еліти. «Одним словом, потрібно виховати еліту... Всі, хто має потенціал для досягнення успіху, мають його досягти. Це передова частина нашого суспільства, і від них залежать темпи нашого прогресу» [9, с. 162].

В цьому сенсі характерні кроки лідера Сінгапуру щодо формування управлінської еліти. За його словами, він витратив майже 40 років на пошуки потрібних людей на відповідальні високі посади. Вивчалися різні корпоративні підходи самих різних фірм і компаній, серед яких Лі Куан Ю визначив компанію «Шелл». Після такого вивчення уряд, добираючи кадри, перейшов від 40 якостей до трьох, які отримали назву «якості гелікоптера»... В чому вони полягають? Уміння аналізувати; точна логічна оцінка фактів; зосередженість на головному, уміння виділяти головне. Проте цього недостатньо... Люди повинні мати відчуття реальності... Однак якщо Ви просто реаліст, ви стаєте пішоходом, плебеєм, Ви не станете переможцем. Отже, Ви також маєте бути здатним піднятися над реальністю i сказати: це теж можливо - тобто мати уяву» [7, c. 175].

На думку Лі Куан Ю, в кожному суспільстві на одну тисячу новонароджених дітей припадає відповідний відсоток майже геніїв, тих, чий інтелект вищий від середнього рівня звичайних дітей і дурнів... «Саме число майже геніїв i тих, чий інтелект вищий від середнього рівня, в підсумку визначає майбутнє суспільство, в якому ці діти народились [7, c. 157].

Нарешті, слід навести ще один висновок великого стратега і лідера Сінгапуру, що підкреслює первинність людської діяльності у формуванні потужної країни (і що більш, ніж актуально для України): «Успіх Сінгапуру як процвітаючою демократії 3 чесною адміністрацією або його повний провал і скочування до диктатури з адміністрацією, що погрузла в корупції, залежатиме від кількості освічених чоловіків і жінок, готових взяти на себе свою частку відповідальності за майбутнє країни, а не дивитися на те, як ця країна скочуватиметься донизу» [7, с. 146].

Отже, побудувати економічно потужну країну Сінгапур вдалося, в першу чергу, завдяки вмілому (майже ідеальному) використанню iii людського потенціалу, видатною часткою якого є сам Лі Куан Ю. Він зумів організувати відповідну систему управління в державі зі здібними до цього працівниками. При цьому сам Лі Куан Ю - це людина зі стратегічним мисленням, що базується на аналітико-пізнавальній активності та уяві, з твердим характером, є дійсним патріотом 3 високим рівнем загальнолюдської моралі.

В якійсь мірі до цього ідеалу наближувалася Японія, яка перша зі східних країн зробила в своєму розвитку опору на людські ресурси (діяльність) і створила «економічне диво» в післявоєнні роки. Обумовлено це слабкими природними ресурсами (немає нафти, газу, залізної руди та ін.), а головне - прагненням управлінської еліти зробити країну високорозвиненою і економічно потужною. Наприклад, успіх Японії щодо підйому національної економіки Джордж Фрідмен (автор наукового бестселера «Наступні 100 років: прогноз подій XXI століття») пояснював так: «У Японії здібна правляча еліта, яка поновлюється новими представниками на основі оцінки заслуг, та винятково дисципліноване населення, готове слідувати за своєю елітою» [13]. В сучасній Україні все навпаки.

Крім того, в Японії для досягнення більш високої якості продукції і продуктивності праці на підприємствах, було використано відповідні соціальні технології. Наприклад, працівникам навіювалась ідея, що кожний 3 них виконує свою роботу для споживача, яким $€$ наступний за операцію працівник. Оскільки образ споживача для японської економіки, яка орієнтується на експорт, був майже «святим», кожний $з$ працівників намагався виконувати своє завдання найкращим чином. Тобто формується соціальний ланцюжок якості, в якому 
самі працівники більш ретельно працюють не тільки на рівні свідомості, але ще і тому, що наступна ланка цього ланцюжка $є$ контролером попередньої. Висока продуктивність праці досягалося ще й тим, що в кожній організації прагнули сприяти працівникам знайти будь-яку «сродню» працю (за Г. Сковородою), яка відповідає професійно-особистісним якостям працівників. Для цього функціонували служби управління кар'єрою персоналу, які робили це за специфічною технологією.

Що стосується інноваційної діяльності, яка б забезпечувала конкурентоспроможність японської економіки на зовнішньому ринку, то він виокремлював два напрямки. Один 3 них був пов'язаний $з$ організацією швидкого втілення в практику досягнень науково-технічного прогресу, другий - 3 організацією на підприємствах «гуртків якості», які охоплювали більшість працюючих.

Отже, як сінгапурський, так і японський феномен можна пояснити одним - умінням використовувати людський потенціал країни в інтересах суспільства і самих носіїв цього потенціалу.

Висновки та перспективи подальших досліджень. Дослідження, що проведені авторами статті головним чином на основі вив- чення закордонних джерел, підтверджують те, що тільки якість людських ресурсів забезпечує підвищення конкурентоспроможності економік будь-яких країн. Доведено, що ці ключові положення якості людських ресурсів в першу чергу стосуються управлінської, політичної і економічної еліти.

В Україні протягом всіх років незалежності управління еліта не відповідала цим ключовим положенням. Це призвело до виникнення надмірної корупції, надзбагаченням одних за рахунок інших, останнього місця в Свропі за ВВП на душу населення i міграції мільйонів українців за кордон для пошуку кращої долі.

Тому подальші дослідження в контексті підвищення конкурентоспроможності економіки $є$ сенс проводити за двома ключовими напрямами. Перший стосується модернізації державно-управлінського механізму 3 налагодженням чіткого зворотного зв'язку за кінцевими результатами діяльності керівників владних структур. Другий напрям пов'язаний 3 людиноцентричною цілеорієнтацією системи освіти на сприяння визначення на кваліментричній основі професійно-особистих якостей здобувачів освіти та прищеплення їм інтересу до самопізнання власного “ $Я$ ”.

\section{Список використаних джерел:}

1. Аджемоглу Д., Робінсон Дж. Чому нації занепадають / пер. с англ. О. Дем’янчука. Київ : Наш Формат, 2016. 440 с.

2. Головатий М.Ф., Дмитренко Г.А., Солодков В.Т. Оздоровлення нації в об’єктиві науки, або Доля України: як ії змінити: науково-публіцистичне видання, 2-ге видання, доповнене. Київ : ДКС-Центр, 2019. $280 \mathrm{c}$.

3. Головач Н.В., Дмитренко Г.А. Системне формування нового покоління нації: гуманістичний контекст : монографія. Київ : ДКС-Центр, 2019. 352 с.

4. Дмитренко Г.А. Системне управління: унікальний людиноцентричний вектор підвищення ефективності державно-управлінського механізму в Україні : наукове видання. Київ : ДКС-центр, 2019. $146 \mathrm{c}$.

5. Дмитренко Г.А., Хлівна І.В. Концептуальні та технологічні засади підвищення конкурентоспроможності національної економіки і системи освіти в процесі їх модернізації : монографія. Умань : видавець «Сочинський М.М.», 2017. 306 с.

6. Друкер П.Ф. Задачи менеджмента в XXI веке / пер. з англ. Н.М. Макарова. Москва : Вільямс, 2001. $272 \mathrm{c}$.

7. Лі Куан Ю. Роздуми великого лідера про майбутнє Китаю, США та світу / ред. Г. Елісон, Р.Д. Блеквілл, Е. Вайн; пер. 3 англ. О. Лобастовой. Київ : Вид. група КМ-БУКС, 2018. 224 с.

8. Макконнелл К.Р., Брю С.Л., Флинн Ш.М. Экономикс: принципы, проблемы и политика / пер. с англ. 19-е изд. Москва : НИЦ Инфра. М., 2017. 1028 с.

9. Сковорода Г. Повне зібрання творів. Т.1-2. Київ : Наукова думка, 1973. 570 с.

10. Стадвелл, Джо. Чому Азії вдалося. Успіхи і невдачі найдинамічнішого регіону світу / Джо Стадвелл; пер. $з$ англ. Олександра Цехановська. Київ : Наш формат, 2017. 448 с.

11. Тейлор Ф.У. Принципы научного менеджмента : пер.с англ. А.И. Зак. Москва : «Журнал «Контроллинг», 1991. 104 с.

12. Фишер С., Дорнбуш Р., Шмалензи Р. Экономика : пер. с англ. со 2-го изд. Москва : Дело ЛТД, 1993. $864 \mathrm{c}$.

13. Фрідман Дж. Следующие 100 лет. Прогноз XXI века. Москва : Эксмо, 2010. 336 с.

14. Щекин Г.В. Основы кадрового менеджмента : Учебник. 5-е изд., стеротип. Київ : МАУП, 2004. $832 \mathrm{c}$. 


\section{References:}

1. Adzhemoglu D., Robinson Dzh. (2016) Chomu nacii zanepadajut [Why nations are declining]. Kyiv: Nash format. (in Ukrainian)

2. Holovatyi M.F., Dmytrenko H.A., Solodkov V.T. (2019) Ozdorovlennia natsii v obiektyvi nauky, abo dolia Ukrainy: yak yii zminyty [Nation's healing in the lens of science, or the fate of Ukraine: how to change it]. Kyiv: DKS-Tsentr. (in Ukrainian)

3. Holovach N.V., Dmytrenko H.A. (2019) Systemne formuvannia novoho pokolinnia natsii: humanistychnyi kontekst [Systematic formation of a new generation of nation: humanistic context]. Kyiv: DKS-Tsentr. (in Ukrainian)

4.Dmytrenko H.A. (2019) Systemne upravlinnia: unikalnyi liudynotsentrychnyi vektor pidvyshchennia efektyvnosti derzhavno-upravlinskoho mekhanizmu v Ukraini [System management: a unique human-centric vector for improving the efficiency of public administration in Ukraine]: naukove vydannia. Kyiv: DKS-tsentr. (in Ukrainian)

5.Dmytrenko H.A., Khlivna I.V. (2017) Kontseptualni ta tekhnolohichni zasady pidvyshchennia konkurentospromozhnosti natsionalnoi ekonomiky $i$ systemy osvity $v$ protsesi yikh modernizatsii : monohrafia [Conceptual and technological principles of increasing the competitiveness of the national economy and education system in the process of their modernization]. Uman: vydavets «Sochynskyi M.M.». (in Ukrainian)

6. Druker P.F. (2001) Zadachi menedzhmenta v XXI veke [Management Objectives in the 21st Century]. Moskow: Vil'yams. (in Russian)

7. Li Kuan Yu (2018) Rozdumy velykoho lidera pro maibutnie Kytaiu, SShA ta svitu [The Great Leader's Reflections on the Future of China, the United States and the world]. Kyiv: KM-BUKS Group. [in Ukrainian].

8. Makkonnell K.R., Bryu S.L., Flinn Sh.M. (2017) Ekonomiks: printsipy, problemy i politika [Economics: principles, problems and politics]. Moskow: NITs Infra-M. (in Ukrainian)

9.Skovoroda H. (1973) Povne zibrannia tvoriv [Complete collection of works]. T.1-2. Kyiv: Naukova dumka. (in Ukrainian)

10. Stadvell Dzho (2017) Chomu Azii vdalosia. Uspikhy i nevdachi naidynamichnishoho rehionu svitu [Why Asia succeeded. Successes and failures of the most dynamic region of the world]. Dzho Stadvell; per. $\mathrm{z}$ anhl. Oleksandra Tsekhanovska. Kyiv: Nash format. (in Ukrainian)

11. Tejlor F.U. (1991) Principy nauchnogo menedzhmenta [Principles of Scientific Management]. Per. s angl. A.I. Zak. Moskow: «ZHurnal «Kontrolling». (in Ukrainian)

12. Fisher S., Dornbush R., SHmalenzi R. (1993) Ekonomika [Economy]. Per. s angl. so 2-go izd. Moskow: Delo LTD. (in Ukrainian)

13. Fridman Dzh. (2010) Sleduyushchie 100 let. Prognoz HKHI veka [The next 100 years. Forecast of the XXI century]. Moskow: Eksmo. (in Russian)

14. Shchekin G.V. (2004) Osnovy kadrovogo menedzhmenta: Uchebnik [Fundamentals of Human Resource Management: A Textbook]. 5-e izd., sterotip. Kyiv: MAUP. (in Russian) 